\title{
Chronic T Cell-Mediated Enteropathy in Rural West African Children: Relationship with Nutritional Status and Small Bowel Function
}

\author{
DAVID I. CAMPBELL, SIMON H. MURCH, MARINOS ELIA, PETER B. SULLIVAN, \\ MUSTAPHA S. SANYANG, BABA JOBARTEH, AND PETER G. LUNN
}

\begin{abstract}
Medical Research Council (U.K.) Keneba [D.I.C., M.S.S., B.J.], The Gambia, West Africa; Centre for
Paediatric Gastroenterology [S.H.M.], Royal Free and University College School of Medicine, NW3 2PF

London, United Kingdom; Institute of Human Nutrition and Metabolism [M.E.], University of

Southampton, Southampton General Hospital, Southampton, United Kingdom; University Department of

Paediatrics [P.B.S.], University of Oxford, Oxford, United Kingdom; Sir James Spence Institute of Child

Health [D.I.C.], Royal Victoria Infirmary, Newcastle-upon-Tyne, United Kingdom; and Department of

Biological Anthropology [P.G.L.], University of Cambridge, Cambridge, United Kingdom
\end{abstract}

\begin{abstract}
ABS
Previous studies from The Gambia have shown that poor
childhood growth is resistant to all but the most intense nutri-
tional intervention and highly dependent on small bowel perme-
ability related to enteropathy. We thus aimed to characterize the
mucosal inflammatory response in rural Gambian children in
relation to intestinal permeability and nutritional status. Small
bowel biopsies were taken from 38 rural Gambian children (age,
0.5-3 y) with a range of nutritional and clinical states (median
weight $z$ score, -4.6 ; range, 0.5 to -6.4 ), $75 \%$ of whom had
diarrhea. Morphometry was performed with immunohistochem-
ical analysis for a range of lineage and activation markers,
including proinflammatory and regulatory cytokines, and related
to current clinical status and gut permeability. Comparison was
made with 19 age-matched U.K. controls. All Gambian children,
regardless of nutritional status, had evidence of chronic cell-
mediated enteropathy with crypt hyperplasia, villous stunting,
and high numbers of intraepithelial lymphocytes. CD25+ cells were 20 -fold higher than in U.K. controls. Although small bowel
\end{abstract}

architecture was independent of nutritional status, $T$ cell numbers rose and $\mathrm{B}$ cell numbers fell with worsening nutrition, and mucosal cytokine production became biased toward a proinflammatory response, with progressive decrease of transforming growth factor- $\beta$ expression. Tropical enteropathy predates the onset of marasmus and is characterized by a cell-mediated $\mathrm{T}_{\mathrm{H}} 1$ response. Protein-energy malnutrition is associated with reduction of regulatory immune responses in the mucosal microenvironment, potentially impairing the mechanisms of oral tolerance.

(Pediatr Res 54: 306-311, 2003)
Abbreviations
IEL, intraepithelial lymphocyte
IFN- $\boldsymbol{\gamma}, \boldsymbol{\gamma}$-interferon
L:M, lactulose:mannitol
PEM, protein-energy malnutrition
TGF- $\boldsymbol{\beta}$, transforming growth factor- $\beta$
TNF- $\boldsymbol{\alpha}$, tumor necrosis factor- $\alpha$

Children from The Gambia show a pattern of growth faltering typical of deprived areas of the developing world (1-4). Growth velocity falls from 4 mo onward, so by age 2 , the mean weight-for-age lies 2 SD below U.K. standards $(z$ score, -2$)$. Previous studies from Keneba, rural Gambia, have identified biochemical and dietary deficiencies in these infants. Despite seemingly well-targeted nutritional intervention with macro-

Received March 8, 2002; accepted August 20, 2002.

Correspondence: Simon Murch, Ph.D., Centre for Paediatric Gastroenterology, Royal Free and University College School of Medicine, Royal Free Campus, Rowland Hill Street, London NW3 2PF, U.K; e-mail: s.murch@rfc.ac.uk

D.I.C was supported by the Medical Research Council. The laboratory work in this study was supported by a grant to S.H.M. in the U.K. Food Standards Agency program on food intolerance.

DOI: 10.1203/01.PDR.0000076666.16021.5E and micronutrients, growth faltering continues (5-9). Massive dietary supplementation (twice recommended values for energy, 2.5 times for protein) produced short-term catch-up growth after gastroenteritis (5), but growth acceleration reached only the population mean, still 2 SD below the U.K., and reversed as soon as the child left the refeeding study $(1,8)$.

The failure of dietary intervention to restore growth has led to search for other factors. Quantitatively the most important association identified is small bowel enteropathy $(2,4,10)$, demonstrated by lactulose:mannitol (L:M) dual sugar permeability testing (11). This assesses both epithelial integrity (exclusion of lactulose entry through intercellular tight junctions) and absorptive capacity (passive absorption of mannitol) (12). During a 1-y period, increased L:M ratio accounted for 
$40 \%$ of growth faltering in Gambian children, with growth impairment related strongly to excess paracellular permeability (11).

"Tropical enteropathy" with villous shortening, crypt hyperplasia, and lymphocyte infiltration of both lamina propria and epithelium has been confirmed in infants from Gambia (8) and many other developing countries $(2,4,10)$. Elevation of inflammatory markers to levels that would prompt investigation for inflammatory bowel disease in the U.K. (13) is frequently seen, even in seemingly well Gambian children. However, little is known of their mucosal immune responses. Infection alone accounts for a minority of cases: bacterial pathogens were isolated in $<12 \%$ in one Keneba study, and viruses were detected more frequently in nondiarrheal control subjects (6). Small bowel bacterial overgrowth and Giardia lamblia infection are found in $>80 \%$ of rural Gambian infants, but neither correlates with growth or gut permeability $(1,14)$.

Evidence that raised permeability may directly cause small bowel inflammation was provided by an important murine study, in which targeted disruption of epithelial cadherins induced severe $\mathrm{T}$ cell-mediated enteropathy, with foci of $\mathrm{T}$ cell activation around leaky crypt epithelium (15). Other work has confirmed the central role of $\mathrm{T}$ cells in causing villous atrophy or eventually mucosal ulceration through tumor necrosis factor- $\alpha$ (TNF- $\alpha)$-mediated matrix degradation (16-19). The pattern of $\mathrm{T}$ cell cytokine production is critical in determining whether such mucosal inflammation occurs. In particular, the role of regulatory lymphocytes producing transforming growth factor- $\beta$ (TGF- $\beta ;-\mathrm{T}_{\mathrm{H}} 3$ cells) and IL-10 (Tr1 cells) is recognized to be of central importance in preventing gut inflammation in response to luminal bacterial challenge (20-22). The aims of this study thus were to correlate nutritional status and intestinal permeability in rural Gambian infants with small bowel morphometry, lymphocyte density and the balance between proinflammatory and regulatory cytokine-producing cells, and to compare with U.K. controls.

\section{METHODS}

Study design. The study was conducted at the Medical Research Council Tropical Medical Research Unit, Fajara, and the WEC mission hospital, Sibanor. The study was approved by the joint Gambian Government/Medical Research Council Ethical Committee for medical research. Children were recruited from clinics or hospital wards and were grouped as follows, based on U.K. 1990 growth standards (Table 1): 1) Normal (weight-for-age $z$ score, -2 ): investigated for gastrointestinal symptoms, e.g. abdominal pain or vomiting, but relatively well nourished and without diarrhea; 2) grade 1 protein energy malnutrition (PEM; weight-for-age $z$ score, -2 to -4$)$ : unresponsive to nutritional supplementation, losing weight; and 3) grade 2 PEM (weight-for-age $z$ score $<-4$ ): severely malnourished with marasmus and/or kwashiorkor.

Informed consent for endoscopy and small bowel biopsy was obtained from parents by a trained field worker. Forty children were recruited and underwent endoscopy under i.v. sedation. All tolerated this without complications. Biopsies were taken into formal saline for histology and liquid nitrogen for immunohistochemistry.

Body weight was measured by Secca baby scale and length was measured by Harpenden stadiometer by trained staff using standard techniques. Stool cultures were available on $90 \%$, all negative for Campylobacter, Shigella, and Salmonella species, although microscopy revealed Giardia in two cases and $A s$ caris lumbricoides in one case. The parents of all children with PEM were counseled, and the children were screened for HIV antibodies. All were negative, consistent with the low HIV prevalence in The Gambia (6). Three patients had recent malaria, two had lower respiratory tract infection, and one had dysentery (microscopy and culture negative).

U.K. control subjects. Specimens were recruited from agematched children investigated at the Royal Free Hospital. All were younger than $3 \mathrm{y}$ and above the third centile for weight. They were endoscoped for vomiting or possible enteropathy, but all investigations were normal and no gastroenterologic diagnosis eventually was made.

Intestinal permeability. Intestinal permeability was performed as described previously $(8,11)$. Urine was collected over $5 \mathrm{~h}$ after a standard dose of L:M mixture, and urinary concentrations were determined by automated enzyme assay.

Quantification of staining. All quantification, for both morphometry and immunohistochemistry, was performed blinded by the first author. U.K. and Gambian samples were treated in the same laboratory using the same techniques. The data were then compared cross-sectionally with measures of nutritional status and intestinal permeability.

Morphometric analysis. Measurement of villous height and crypt depth was performed as previously described (23). Wellorientated crypt-villous units were measured $(\times 400$ magnification) using Imagan 2 software (Kompira, U.K.). An average was obtained from 10 crypt-villus units for each biopsy. Intraepithelial lymphocyte (IEL) numbers were counted within surface epithelium at magnification $\times 1000$. At least 500 epithelial cells were counted, and the final IEL density was expressed per 100 epithelial cells.

Immunohistochemical analysis. Avidin-biotin immunohistochemistry was performed on 7- $\mu \mathrm{m}$ frozen sections. Optimal dilutions had been determined previously on sections of tonsil, spleen, small intestine, and colon (Table 2), and nonprimary

Table 1. Subject nutritional status by group

\begin{tabular}{|c|c|c|c|c|}
\hline Group (n) & Weight $z$ score & Height $z$ score & BMI $z$ score & $\begin{array}{c}\text { No. with } \\
\text { diarrhea }(\%)\end{array}$ \\
\hline Normal (4) & $-1.2(1.3)$ & $0.59(3.5)$ & $-1.8(1.5)$ & 0 \\
\hline Grade 1 PEM (11) & $-3.2(0.89)$ & $-1.6 \quad(0.83)$ & $-2.6(1.7)$ & $7(65)$ \\
\hline
\end{tabular}

Data are medians with interquartile range. BMI, body mass index. 
Table 2. Immunohistochemical antibodies and dilutions used

\begin{tabular}{llc}
\hline \multicolumn{1}{c}{ Antigen } & \multicolumn{1}{c}{ Supplier } & Dilution \\
\hline Cytokeratin & Dako, U.K. & $1: 50$ \\
Perforin & Alexis, MN, U.S.A. & $1: 25$ \\
$\gamma \delta$ T-cell receptor & Becton Dickinson, U.K. & $1: 25$ \\
CD-3 & Dako, U.K. & $1: 40$ \\
CD-4 & Dako, U.K. & $1: 20$ \\
CD-8 & Dako, U.K. & $1: 50$ \\
CD-19 & Dako, U.K. & $1: 50$ \\
CD-25 & Dako, U.K. & $1: 25$ \\
HLA-DR & Dako, U.K. & $1: 40$ \\
TNF- $\alpha$ & Genzyme, Cambridge, MA & $1: 50$ \\
IFN- $\gamma$ & R\&D Systems, U.K. & $1: 50$ \\
TGF- $\beta$ & Genzyme, Cambridge, MA & $1: 10$ \\
IL-10 & R\&D Systems, U.K. & $1: 10$ \\
\hline
\end{tabular}

controls were used throughout, with no significant background staining detected. Antigens were localized using avidin-biotin immunohistochemistry (Vectastain elite, Vecta), after application of $3 \% \mathrm{H}_{2} \mathrm{O}_{2}$ in methanol after the primary antibody to neutralize endogenous peroxidase.

We detected more extensive cytokine immunoreactivity within intestinal tissue than in tonsil or spleen, where individual immunoreactive cells were detected with relatively little background. For $\gamma$-interferon (IFN- $\gamma$ ), there was significant extracellular binding to matrix glycosaminoglycans, as recognized in vitro (24). This was also seen in U.K. controls and probably reflects the complex cytokine-rich environment within the intestinal mucosa $(22,25)$. Preincubation with heparinase II or chondroitinase $\mathrm{ABC}$ removed most of the matrixassociated cytokine (19) but disrupted tissue morphology, and therefore sections were not pretreated in this way. Immunoreactive cell density was determined using a standard eyepiece graticule and stage micrometer, scoring as positive only cells of mononuclear morphology with clear cytoplasmic staining. Specific IEL subtypes (perforin ${ }^{+}$or $\gamma \delta^{+}$) were counted as above.

Statistical analysis. Continuous variables were $\log$ transformed when distributed nonparametrically. Comparison between continuous variables was made using linear regression after checking that a scatterplot demonstrated a true relationship between response and predictor variables.

Height- and weight-for-age were expressed as $z$ scores, relative to 1990 U.K. standards. The effect of age on mucosal morphometry, immunohistochemical findings, and permeability was nonsignificant by regression analysis. Further calculations were therefore not age-corrected. Comparison of medians was performed using the Mann-Whitney $U$ test. Data Desk 6.0 software was used.

\section{RESULTS}

All Gambian children, regardless of nutritional status, showed significant enteropathy. Comparison of mean villous height and crypt depth with established values for European or privileged Brazilian children (2) confirmed that all groups had crypt-hyperplastic villous atrophy. However, the degree of morphometric abnormality alone did not correlate with current nutritional status ( $p=0.7$; Table 3$)$. No significant differences between groups were seen for any morphometric parameter, and there was no correlation with the presence of diarrhea. The median IEL count was $40 \%$, within the range characteristic of celiac disease (26).

Mucosal lymphocyte populations. Representative staining is shown in Fig. 1. The density of $\mathrm{CD}^{+}{ }^{+} \mathrm{T}$ cells within the lamina propria was four to five times higher in Gambian children than in U.K. control subjects (Table 4) but with wide scatter. The proportion of $\mathrm{CD}^{+}$cells was approximately equal between $\mathrm{CD}^{+}$and $\mathrm{CD}^{+}$cells. CD3, CD4, and CD8 cell density increased with worsening malnutrition, although this trend did not reach significance (e.g. CD3 cells $/ \mathrm{mm}^{2}$ against weight $z$ score, $r=0.3, p=0.07)$. $\mathrm{CD} 25^{+}$density was $15-30$ times higher than in U.K. control subjects. However, in contrast to overall $\mathrm{T}$ cell numbers, $\mathrm{CD} 25^{+}$cells fell with worsening malnutrition $\left(\mathrm{CD} 25\right.$ cells $/ \mathrm{mm}^{2}$ against height $z$ score, $r=$ $-0.51, p<0.04)$.

Mean IELs were $>2$ SD above U.K. normals, including $\gamma \delta$ cells well above normal U.K. values of approximately $10 \%$ (27), with higher numbers seen in more malnourished children (Table 4). By contrast, expression of the cytotoxic granule perforin, characteristic of activated cytotoxic lymphocytes, although increased in all groups, was lower in the more malnourished. Further evidence of epithelial activation was demonstrated by strong expression of HLA-DR on crypt epithelium in all groups. Lamina propria $\mathrm{CD} 19^{+} \mathrm{B}$ cells were two to three times denser in Gambian children than in U.K. control subjects, whereas mature plasma cells $\left(\right.$ syndecan $-1^{+}$) were at least 25-30 times higher. In contrast to $T$ cells, the density of both $\mathrm{B}$ and plasma cells decreased with worsening nutritional status, although these trends did not reach statistical significance.

Cytokine immunoreactivity. The distribution of mucosal cytokine immunoreactivity in the 34 Gambian children with sufficient frozen tissue was broadly similar to the U.K. children, although epithelial staining tended to be stronger. Background staining was higher than for lineage markers, and density counting, although performed blinded, was necessarily less precise. Overall, we found that all Gambian groups

Table 3. Morphometry by clinical status

\begin{tabular}{|c|c|c|c|c|}
\hline Clinical group $(n)$ & $\begin{array}{l}\text { Median } \\
\text { crypt depth } \\
(\mu \mathrm{m})\end{array}$ & $\begin{array}{l}\text { Median } \\
\text { villous height } \\
(\mu \mathrm{m})\end{array}$ & $\begin{array}{l}\text { Villous/crypt } \\
\text { ratio }\end{array}$ & $\begin{array}{c}\text { IEL } \\
\text { (per } 100 \text { epithelial cells) }\end{array}$ \\
\hline Normal (4) & $266 \quad(50)$ & $250 \quad(70)$ & $0.81(0.5)$ & $43.2(7.3)$ \\
\hline Grade 1 PEM (11) & $277.9(78.7)$ & $216.2(76.7)$ & $0.80(0.2)$ & $36.8(8.8)$ \\
\hline Grade 2 PEM (27) & $278.2(62.2)$ & $254.6(60.2)$ & $0.84(0.3)$ & $39.2(10.4)$ \\
\hline U.K. controls & $170 \quad(20)$ & $355 \quad(35)$ & $2.1 \quad(0.3)$ & $14 \quad(5)$ \\
\hline
\end{tabular}

No differences seen between Gambian groups by ANOVA. 
A

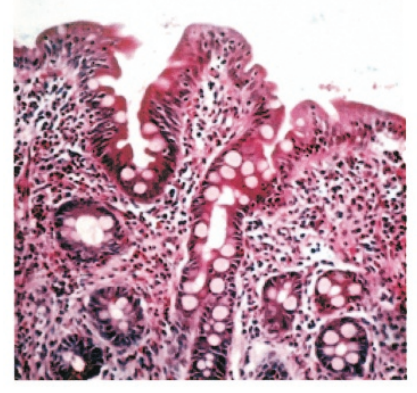

D

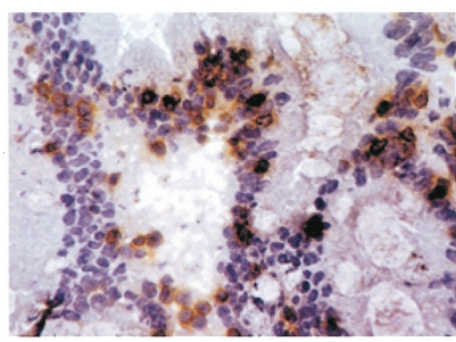

G

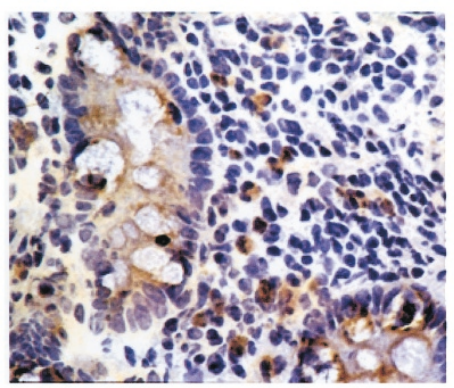

B

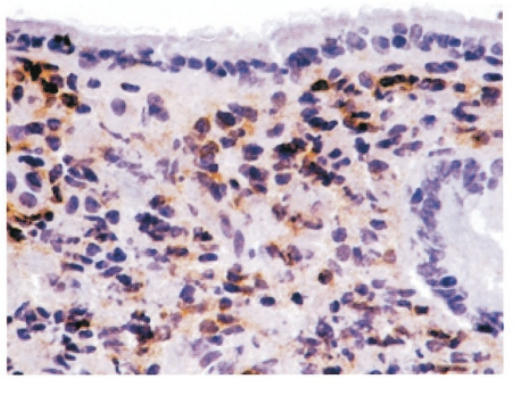

E

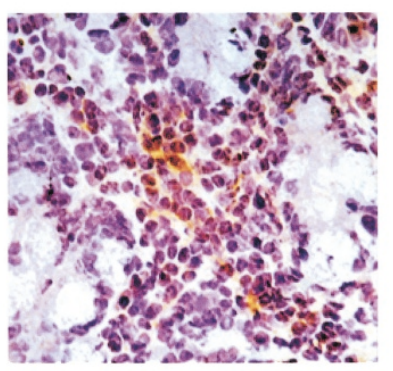

$\mathrm{H}$

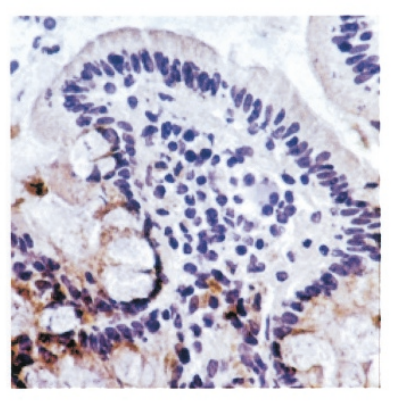

C

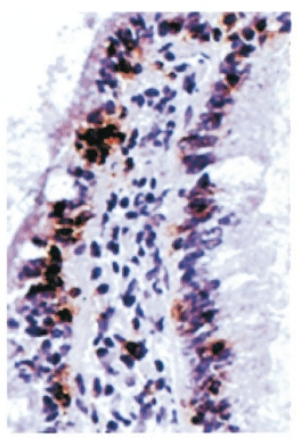

$\mathrm{F}$

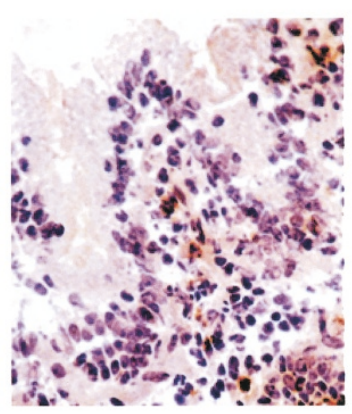

।

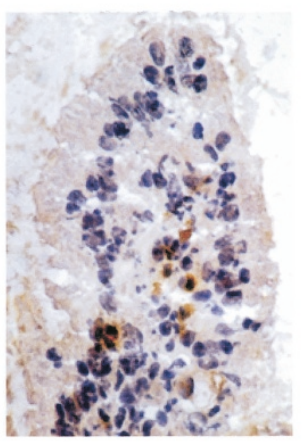

Figure 1. Immunohistochemical analysis of mucosal biopsies from Gambian children. Peroxidase immunohistochemistry was used throughout with positivelystained cells appearing brown. A, Hematoxylin and eosin-stained formalin-fixed biopsy in a marasmic child, showing crypt-hyperplastic villous atrophy and increased lymphocyte density in lamina propria and epithelial compartments. $B, \mathrm{CD} 4$ cells within lamina propria but not epithelium in a child with failure to thrive. $C$, High density of $\gamma \delta$ intraepithelial lymphocytes despite normal villous architecture in marasmic child. $D$, Similar increase in CD $8^{+}$intraepithelial lymphocytes in another marasmic child. $E$, Dense infiltrate of $\mathrm{CD} 25^{+}$cells within the lamina propria in a child with failure to thrive. $F$, TNF- $\alpha$ immunoreactive cells within the lamina propria in marasmic child. $G$, TGF- $\beta^{+}$cells in lamina propria of a child with failure to thrive but not marasmus. TGF- $\beta$ expression is also seen in the epithelium. $H$, Contrasting reduction of mucosal and epithelial TGF- $\beta^{+}$cell density in a marasmic child. $I$, IL- $10^{+}$cells within the lamina propria of a marasmic Gambian child. Note the relative preservation of villous architecture.

Table 4. Small bowel mucosal inflammatory cell densities (per $\mathrm{mm}^{2}$ ) in Gambian and U.K. children (median and range given)

\begin{tabular}{|c|c|c|c|c|c|c|c|c|c|}
\hline Group $(n)$ & & CD3 & CD4 & CD8 & CD19 & Syndecan-1 & $\mathrm{CD} 25$ & $\begin{array}{c}\text { IEL- } \\
\text { perforin }+(\%)\end{array}$ & IEL- $\gamma \delta+$ \\
\hline $\begin{array}{l}\text { U.K. controls } \\
\text { (19) }\end{array}$ & 291 & $(169-910)$ & $301 \quad(112-531)$ & $159(90-400)$ & 177 (41-308) & ND & $19(4-75)$ & $2.6 \quad(0.2-7.9)$ & ND \\
\hline Normal (3) & $1072 *$ & $(856-1385)$ & $572 *(412-622)$ & $370 *(345-419)$ & $346 \dagger(310-385)$ & & $578 \dagger(500-656)$ & $39.3 \dagger(31-47)$ & $28.4(\mathrm{n}=1)$ \\
\hline $\begin{array}{l}\text { Grade } 1 \\
\text { PEM (8) }\end{array}$ & $1128 \S$ & $(708-1410)$ & $661 \S(385-1375)$ & $400 \S(257-841)$ & $681 \S(250-1068)$ & $341 \quad(156-754)$ & $475 \S(216-831)$ & $48 \S \quad(22-99)$ & $38.9(31-74)$ \\
\hline $\begin{array}{l}\text { Grade } 2 \\
\quad \text { PEM (23) }\end{array}$ & $1446 \S$ & $(904-2175)$ & $556 \S(244-1556)$ & $416 \S(219-1489)$ & $361 \$(194-956)$ & $228 \S(46-500)$ & $331 \S(106-869)$ & $(7.7-102)$ & $37.2(11-99)$ \\
\hline
\end{tabular}

Comparing Gambian and U.K. controls Mann Whitney $U^{*} p<0.01, \dagger p<0.02 ; \ddagger p>0.1 ; \S p<0.001$. ND, not done.

showed substantial increase of lamina propria cytokineimmunoreactive cell density above U.K. control subjects, with approximately $200-450$ cytokine-immunoreactive mononuclear cells $/ \mathrm{mm}^{2}$, compared with $30-80 / \mathrm{mm}^{2}$ in U.K. control subjects. Broadly similar densities were seen for both proinflammatory cytokines (IFN- $\gamma$ and TNF- $\alpha$ ) and putative regulatory cytokines (IL-10 and TGF- $\beta$ ) cytokines. Epithelial expression of TGF- $\beta$ was also enhanced. However, as nutritional 
status decreased, there was clear reduction in the mucosal density of TGF- $\beta^{+}$cells, with median density of 420 cells/ $\mathrm{mm}^{2}$ in the early PEM group and 250 cells $/ \mathrm{mm}^{2}$ in those with advanced PEM. The marasmic children also showed reduction of epithelial TGF- $\beta$ expression (Fig. 1). There was no evidence of similar reduction in the density of TNF- $\alpha^{+}, \mathrm{IFN}-\gamma^{+}$, or IL- $10^{+}$cells. The relatively well-nourished Gambian control subjects thus showed a ratio of regulatory (TGF- $\beta+$ IL-10) to proinflammatory (IFN- $\gamma+$ TNF- $\alpha$ ) cytokine cell density of approximately $3: 1$, compared with a reversed ratio of $<1: 1$ in those at the extreme end of grade 2 PEM, i.e. with more proinflammatory than regulatory lymphocytes.

Intestinal permeability. Small intestinal permeability was substantially higher in the Gambian infants than in U.K. control subjects, as previously reported (11) (Table 5). However, there was no overall relationship between nutritional status and $\mathrm{L}: \mathrm{M}$ ratio or with percentage recoveries of lactulose and mannitol. By contrast, there were significant relationships between mucosal B lymphocyte density $(r=0.57, p<0.05)$ and both IEL $(r=0.51, p<0.02)$ and perforin ${ }^{+}$IEL $(r=-0.64$, $p<0.03$ ) numbers and the L:M ratio.

\section{DISCUSSION}

This study demonstrated that Gambian children have evidence of a cell-mediated enteropathy, across a range of nutritional states. Although a recent study reported cell-mediated inflammation associated with tropical enteropathy (28), this is the first study of its kind in children that has specifically studied markers of cell-mediated inflammation and proinflammatory cytokines.

The ability to study enteropathy in African children without malnutrition or diarrhea is limited for clear ethical reasons. In the course of clinical practice, a number of children who had chronic abdominal pain (thus not ideal controls) were able to be studied, providing a limited insight into enteropathy in otherwise well children. Their L:M ratios, however, were similar to previously reported asymptomatic Gambian children (11). Compared with developed-world children $(2,4,22,26)$, crypt-hyperplastic villous atrophy was found across the spectrum of nutritional states. Such morphometric changes are seen in many diseases caused by mucosal $\mathrm{T}$ cell activation, such as celiac disease (22). Morphometry did not differentiate between well and severely malnourished children, as previously reported (8). Thus, tropical enteropathy and malnutritionassociated enteropathy may represent a continuum rather than distinct conditions. Worsening nutritional status produced consistent changes. $\mathrm{CD} 3, \mathrm{CD} 4$, and $\mathrm{CD} 8$ cells increased in the

Table 5. Changes in intestinal permeability within the Gambian study groups

\begin{tabular}{lllc}
\hline \multicolumn{1}{c}{ Group $(n)$} & \multicolumn{1}{c}{ L:M } & $\begin{array}{c}\text { \% Recovery } \\
\text { of lactulose }\end{array}$ & $\begin{array}{c}\text { \% Recovery } \\
\text { of mannitol }\end{array}$ \\
\hline Normal $(4)$ & $0.53(0.4-1.3)$ & $0.13(0.006-0.9)$ & $6.3(0.3-12.1)$ \\
Grade 1 PEM (11) & $0.47(0.02-2.20)$ & $0.05(0.008-0.90)$ & $3.3(0.83-11.7)$ \\
Grade 2 PEM (26) & $0.73(0.14-2.2)$ & $0.03(0.001-0.44)$ & $1.50(0.11-7.6)$ \\
\hline
\end{tabular}

ANOVA $p=0.2$.

U.K. normal: L:M ratio $<0.1, \%$ recovery of lactulose and mannitol $(<0.1$ and $11-15 \%$ respectively). lamina propria, as did $\gamma \delta^{+}$IELs, whereas cells expressing CD25 or producing cytokines declined in severe PEM.

Mucosal proinflammatory cytokines were elevated in this study, despite stool culture and microscopy showing no evidence of clear parasites and common bacterial pathogens. However, we could not absolutely exclude the presence of all pathogenic organisms, such as pathogenic Escherichia coli strains. Similar upregulation of TNF- $\alpha$ or IFN- $\gamma$ may be seen in a variety of inflammatory small bowel conditions such as Crohn's disease and celiac disease $(29,30)$. We localized cytokines at the protein but not mRNA level and recognize that additional methods of studying cytokine mRNA production will be needed in future studies to confirm these changes in severe malnutrition. Significant clinical and logistical difficulties prevented this in the current study. Multiple biopsies from such ill children were not regarded as ethically acceptable. We recognize the difficulties in precise quantification of cytokine production by immunohistochemistry and the need to optimize staining on a variety of tissues. In addition, identification of cells on morphologic grounds, without simultaneous lineage marker staining, makes formal confirmation of lymphocyte status uncertain. With these reservations, we noted a seemingly consistent trend in reduction of regulatory cytokine expression with worsening malnutrition, together with a decrease in the number of activated $\mathrm{CD} 25^{+}$cells.

Although the role of $\mathrm{T}$ cells in enteropathy is well established $(16-18,31)$, there has been recent recognition of the importance of regulatory cytokines (20-22). Transfer of cells that produce TGF- $\beta$ or IL- 10 prevents murine colitis, whereas deficiency of either cytokine causes mucosal inflammation $(20-22,32-35)$. Tolerance to low-dose dietary antigen is actively mediated by TGF- $\beta$-producing $\mathrm{T}_{\mathrm{H}} 3$ cells $(22,36)$, whereas high-dose tolerance is thought to be due to $\mathrm{T}$ cell anergy after epithelial antigen presentation $(22,35,36)$. In addition, CD4 +CD25 + cells have recently been demonstrated to have potent regulatory functions (37), and it thus is notable that there was reduction in CD25 cells with worsening nutritional status. Tolerance can be broken by pathogens either by induced IL-12 expression, causing deviation of Peyer's patch responses toward $\mathrm{T}_{\mathrm{H}} 1(34,35)$, or by disruption of the epithelial barrier, allowing passage of intact antigen to subepithelial antigen presenting cells $(22,38,39)$.

This study demonstrated increased permeability and seeming dominance of IFN- $\gamma$ over TGF- $\beta$ in marasmus, both of which could undermine oral tolerance. IFN- $\gamma$ not only blocks TGF- $\beta$ signaling (40) but also induces epithelial leakiness (41), although this latter effect is opposed by TGF- $\beta$ (42) and IL-10 (43). We suggest that a vicious circle may become established, whereby pathogens break oral tolerance by disruption of the epithelial barrier and the consequent dominance of IFN- $\gamma$ over TGF- $\beta$ maintains epithelial leakiness while intake of the sensitizing antigen(s) continues. There is evidence from marasmic Gambian children that such a process does occur, as nutritional rehabilitation actually increases paracellular permeability (8). If confirmed in further studies, then these findings may explain the link between gut leakiness and mucosal inflammation in tropical children as a progressive breakdown in oral tolerance mechanisms as marasmus develops. Reports from other developing countries 
confirm sensitization to cow milk and soya $(44,45)$. If this response occurs in malnourished children from other countries, then they may be at increased risk of developing food-sensitive enteropathy to a variety of macromolecules.

We have shown a $\mathrm{T}_{\mathrm{H}}$ 1-type enteropathy in relatively small numbers of malnourished Gambian children, although their histologic and permeability findings suggest a broader applicability. Little is known of the cellular inflammatory events that occur in the intestinal mucosa in severe tropical malnutrition, despite its being a common syndrome, attended with unacceptably high mortality rates $[30-40 \%(2,3)]$ and frequent relapse. Management issues are being addressed by the World Health Organization Integrated Child Health Program. The situation of the child with severe persistent diarrhea and PEM needs further consideration. Although the majority of children respond to cautious rehydration and nutritional rehabilitation, a proportion will continue with intractable diarrhea despite the use of a hypoallergenic diet such as comminuted chicken. Further understanding of the enteropathy in these children is critical to improve outcome.

Acknowledgments We are indebted to the parents and children who attend the Medical Research Council Hospital and WEC Mission Hospitals The Gambia for their cooperation and to James Mendy, Sister Thomas, and Dr. Tumani Corrah for indispensable assistance. We thank the Missionaries at Sibanor for great kindness and hospitality. We are also grateful to John Walker-Smith and Alan Phillips for generous help and valuable input.

\section{REFERENCES}

1. Rowland MGM, Cole TJ, McCollum JPK 1981 Weanling diarrhoea in The Gambia: implications of a jejunal intubation study. Trans R Soc Trop Med Hyg 75:215-218

2. Fagundes-Neto U, Viaro T, Wehba J, da Silva Patricio F, Reis, Machado NL 1984 Tropical enteropathy (environmental enteropathy) in early childhood: a syndrome caused by contaminated environment. J Trop Pediatr 30:204-209

3. Garcia S 1968 Malabsorption and malnutrition in Mexico. Am J Clin Nutr 21:10661076

4. Walker-Smith JA, 1999 Gastroenteritis and its sequelae. In Walker-Smith JA, Murch $\mathrm{SH}$ (eds) Diseases of the Small Intestine in Childhood, 4th Ed. Isis Medical Media, Oxford, pp 119-194

5. Hoare S, Poppitt SD, Prentice AM, Weaver LT 1996 Dietary supplementation and rapid catch-up growth after acute diarrhoea in childhood. Br J Nutr 76:479-490

6. Rowland MGM, Davies H, Patterson S 1978 Viruses and diarrhoea in West Africa and London: a collaborative study. Trans R Soc Trop Med Hyg 72:95-98

7. Sullivan PB, Mascie-Taylor CGN, Lunn PG, Northrop-Clewes CA, Neale G 1991 The treatment of persistent diarrhoea and malnutrition: long term effects of in-patien rehabilitation. Acta Paediatr Scand 80:1025-1030

8. Sullivan PB, Lunn PG, Northrop-Clewes C, Crowe PT, Marsh MN, Neale G 1992 Persistent diarrhea and malnutrition - the impact of treatment on small bowel structure and permeability. J Pediatr Gastroenterol Nutr 14:208-215

9. Schroeder DG, Brown KH 1994 Nutritional status as a predictor of child survival: summarising the association and quantifying its global impact. Bull World Health Organ 72: 569-579

10. Schneider RE, Viteri FE 1972 Morphological aspects of the duodenojejunal mucosa in protein-calorie malnourished children and during recovery. Am J Clin Nutr 25:1092-1102

11. Lunn PG, Northrop-Clewes CA, Downes RM 1991 Intestinal permeability, mucosal injury, and growth faltering in Gambian infants. Lancet 338:907-910

12. Juby LD, Rothwell J, Axon AT 1989 Lactulose/mannitol test: an ideal screen for celiac disease. Gastroenterology 96:79-85

13. Beattie RM, Walker-Smith JA, Murch SH 1995 Indications for investigation of chronic gastrointestinal symptoms. Arch Dis Child 73:354-355

14. Lunn PG, Erinoso HO, Northrop-Clewes CA, Boyce SA 1999 Giardia intestinalis is unlikely to be a major cause of the poor growth of rural Gambian infants. J Nutr 129:872-877
15. Hermiston ML, Gordon JI 2071995 Inflammatory bowel disease and adenomas in mice expressing a dominant negative N-cadherin. Science 270:1203-1201

16. Lionetti P, Breese E, Braegger CP, Murch SH, Taylor J, MacDonald TT 1993 T cell activation can induce either mucosal destruction or adaptation in cultured human fetal small intestine. Gastroenterology 105:373-381

17. Pender SLF, Lionetti P, Murch SH, Wathen N, MacDonald TT 1996 Proteolytic degradation of intestinal mucosal extracellular matrix after lamina propria $\mathrm{T}$ cell activation. Gut 39:284-290

18. Pender SL, Fell JM, Chamow SM, Ashkenazi A, MacDonald TT 1998 A p55 TNF receptor immunoadhesin prevents $\mathrm{T}$ cell-mediated intestinal injury by inhibiting matrix metalloprotease production. J Immunol 160:4098-4103

19. Murch SH, MacDonald TT, Walker-Smith JA, Levin M, Lionetti P, Klein NJ 1993 Disruption of sulphated glycosaminoglycans in intestinal inflammation. Lancet 341:711-714

20. Powrie F, Carlino J, Leach MW, Mauze S, Coffman RL 1996 A critical role for transforming growth factor- $\beta$ but not interleukin 4 in the suppression of T helper type 1-mediated colitis by CD45RB ${ }^{\text {low }}$ CD4 + T cells. J Exp Med 183:2669-2674

21. Groux H, O'Garra A, Bigler M, Rouleau M, Antonenko S, de Vries JE, Roncarolo MG 1997 A CD4 $^{+}$subset inhibits antigen-specific T-cell responses and prevents colitis. Nature 389:737-742

22. Walker-Smith JA, Murch SH 1999 The immune system of the small intestine. In Diseases of the Small Intestine in Childhood, 4th Ed. Isis Medical Media, Oxford, pp $45-61$

23. Maluenda C, Phillips AD, Briddon A, Walker-Smith JA 1984 Quantitative analysis of small intestinal mucosa in cow's milk sensitive enteropathy. J Pediatr Gastroenterol Nutr 3:349-356

24. Lortat-Jacob H, Kleinman HK, Grimaud J-A 1991 High affinity binding of interferon- $\gamma$ to a basement membrane (matrigel). J Clin Invest 87:878-883

25. Fiocchi C 1997 Intestinal inflammation: a complex interplay of immune and nonimmune cell interactions. Am J Physiol 273:G769-G775

26. Savidge TC, Shmakov AN, Walker-Smith JA, Phillips AD 1996 Epithelial cell proliferation in childhood enteropathies. Gut 39:185-193

27. Walker-Smith JA, Murch SH 1999 Coeliac disease. In: Diseases of the Small Intestine in Childhood, 4th Ed. Isis Medical Media, Oxford, pp 235-277

28. Veitch AM, Kelly P, Zulu IS, Segal I, Farthing MJG 2001 Tropical enteropathy: T-cell mediated crypt hyperplastic enteropathy. Eur J Gastroenterol Hepatol 13:11751181

29. Murch SH, Braegger CP, Walker-Smith JA, MacDonald TT 1993 Location of tumour necrosis factor $\alpha$ by immunohistochemistry in chronic inflammatory bowel disease. Gut 34:1705-1709

30. Breese EJ, Kumar P, Farthing MJ, MacDonald TT 1994 Interleukin-2 and interferon- $\gamma$ producing cells in the lamina propria in celiac disease. Dig Dis Sci 39:2243

31. Thompson FM, Mayrhofer G, Cummins AG 1996 Dependence of epithelial growth of the small intestine on $\mathrm{T}$ cell activation during weaning in the rat. Gastroenterology 111:37-44

32. Boivin GP, O'Toole BA, Ormsby IE, Diebold RJ, Eis MS, Doetschman T, Kier AB 1995 Onset and progression of pathological lesions in transforming growth factor$\beta 1$-deficient mice. Am J Pathol 146:276-288

33. Kühn R, Löhler J, Rennick D, Rajewsky K, Müller W 1993 Interleukin-10 deficient mice develop chronic enterocolitis. Cell 75:263-274

34. Strober W, Kelsall B, Fuss I, Marth T, Ludviksson B, Ehrhardt R, Neurath MF 1997 Reciprocal IFN- $\gamma$ and TGF- $\beta$ responses regulate the occurrence of mucosal inflammation. Immunol Today 18:61-64

35. Groux H, Powrie F 1999 Regulatory T cells and inflammatory bowel disease. Immunol Today 20:442-446

36. Friedman A, Weiner HL 1994 Induction of anergy or active suppression following oral tolerance is determined by antigen dosage. Proc Natl Acad Sci U S A 91:66886692

37. Jonuleit H, Schmitt E, Kakirman H, Stassen M, Knop J, Enk AH 2002 Infectious tolerance: human $\mathrm{CD} 25(+)$ regulatory $\mathrm{T}$ cells convey suppressor activity to conventional CD4(+) T helper cells. J Exp Med 196:255-260

38. Walker-Smith JA, Murch SH 1999 Enterocyte proliferation and functions. In: Diseases of the Small Intestine in Childhood, 4th Ed. Isis Medical Media, Oxford, pp 29-43

39. Murch SH 1997 The molecular basis of intractable diarrhoea. Baillières Clin Gastroenterol 11:413-440

40. Ulloa L, Doody J, Massague J 1999 Inhibition of transforming growth factor- $\beta$ SMAD signalling by the interferon- $\gamma /$ STAT pathway. Nature 397:710-713

41. Adams RB, Planchon SM, Roche JK 1993 IFN- $\gamma$ modulation of epithelial barrier function. Time course, reversibility, and site of cytokine binding. J Immunol 150:2356-2363

42. Planchon SM, Martins CA, Guerrant RL, Roche JK 1994 Regulation of intestinal epithelial barrier function by TGF- $\beta 1$. Evidence for its role in abrogating the effect of a T cell cytokine. J Immunol 153:5370-5379

43. Madsen KL, Lewis SA, Tavernini MM, Hibbard J, Fedorak RN 1997 Interleukin 10 prevents cytokine-induced disruption of T84 monolayer barrier integrity and limits chloride secretion. Gastroenterology 113:151-159

44. Iyngkaran N, Yadav M, Boey CG, Kamath KR, Lam KL 1989 Causative effects of cow's milk protein and soy protein on progressive small bowel mucosal damage. J Gastroenterol Hepatol 4:127-136

45. Lifshitz F, Fagundes-Neto U, Ferreira VC, Cordano A, Ribeiro Hda C 1990 The response to dietary treatment of patients with chronic post-infectious diarrhea and lactose intolerance. J Am Coll Nutr 9:231-240 